\title{
9 Long-term Integrated Archaeological Prospection at the Roman Town of Carnuntum/Austria
}

\author{
Wolfgang Neubauer, Michael Doneus, Immo Trinks, Geert \\ Verhoeven, Alois Hinterleitner, Sirri Seren and Klaus Löcker
}

\section{Introduction}

Approximately $40 \mathrm{~km}$ south-east of Vienna on the southern bank of the Danube river, the site of the Roman military camp and civil town of Carnuntum constitutes the largest archaeological landscape in Austria (Jobst 1983; Vorbeck and Beckel 1973; Doneus et al. 2001), covering some 650 ha of archaeological area between the villages of PetronellCarnuntum and Bad Deutsch Altenburg (Kandler 1994; 1997; 1998; Kandler et al. 2001a; 2001b). As the capital of the Roman province of Pannonia, Carnuntum was an important town during the first four centuries of the first millennium $\mathrm{AD}$. So far only small parts of this archaeological site and the surrounding landscape have been investigated using traditional archaeological methods. Considerable archaeological excavation activity took place between 1877 and 1917, uncovering a larger number of structures at Carnuntum than at any period since (Jobst 1983). While in the nineteenth century Carnuntum still was named 'Pompeii at the gates of Vienna' due to the exceptionally good state of preservation of its ruins, this situation has changed drastically in the meantime. Intensive farming involving deep ploughing, infrastructure development, the construction of new housing estates in the nearby villages, and active looting by treasure hunters has caused a dramatic increase in the irreversible erosion of the archaeological stratification and destruction of this important cultural heritage site.

In order to counteract this destructive development, both archaeologists and planners first need to know the exact location and extent of the threatened archaeological structures. While large-scale archaeological excavation and trenching has been used in the past for the investigation and reconstruction of the ancient city layout, modern archaeology increasingly makes use of non-invasive means for the exploration and mapping of the buried subsurface. In particular aerial archaeology and geophysical archaeological prospection methods have proven to be ideally suited survey methods of great value for the mapping and documentation of Roman city sites, as exemplified by the archaeological prospection of the ancient town of Carnuntum. 
Following the strategy described here over the past 15 years, considerable areas have been investigated at Carnuntum using many aerial photographs and much topographical data. High-resolution near-surface geophysical survey methods have been tested, developed and applied for the prospection of extensive areas within the archaeological park of Carnuntum, while novel, specialist tools for the efficient processing and display of the acquired geophysical data have been developed in parallel. The archaeological information contained in the aerial photographs, as well as in the high-resolution geophysical data, is converted into archaeologically useful and valuable information through the process of integrative archaeological interpretation within the framework of Geographical Information Systems (GIS) (Lorra 1996; Neubauer 2004).

The resulting archaeological maps and plans of individual buildings, streets and Roman infrastructure allow the virtual reconstruction of the city layout and the development of the ancient land- and townscapes in two and three dimensions, providing scholars, planning authorities and the public alike with detailed information about the ancient city of Carnuntum. This non-invasive and sustainable approach to archaeological survey of Roman city sites provides a model for modern, time- and cost-efficient archaeology, taking into account not only the individual archaeological site but also its surrounding landscape, an approach in full compliance with the Valetta Convention (Council of Europe 1992).

\section{Integrative strategy for the survey of Roman city sites}

An integrative strategy (Neubauer et al. 1999; Doneus et al. 2002; Doneus and Neubauer 2005) for the survey of Roman city sites combining systematic, large-scale aerial archaeology and ground-based high-resolution geophysical prospection (Neubauer 1990; Scollar et al. 1990; Gaffney and Gater 2003; English Heritage 2008) through joint archaeological interpretation of the digital data in GIS environments is presented here. This strategy is outlined using the example of the Roman town of Carnuntum (Eder-Hinterleitner et al. 2003).

The University of Vienna, the Austrian Archaeological Institute and the County of Lower Austria initiated the compilation of a thorough inventory of available aerial photographs and their systematic analysis with the aim of generating a complete overview of the archaeological site of Carnuntum. The first geophysical surveys of Carnuntum, sporadically executed since the early 1990s, generated promising results regarding the location of a cemetery road, parts of the auxiliary camp and the vicus (Kandler 1994), and in particular in the civil town (Neubauer and Eder-Hinterleitner 1997; Kandler 1998). Based on the initial studies further large-scale surveys have been conducted. This work produced exceptional data of outstanding quality. The development of a standardised methodology for the integration of data from archaeological prospection in order to generate a highly detailed and reliable interpretative model is a long standing and continuing research objective. 


\section{Aerial archaeology}

In combination with other non-invasive remote sensing methods, such as airborne hyperspectral scanning (AHS), airborne laser scanning (ALS), and non-invasive geophysical prospection, aerial archaeology is a very cost-effective method for site discovery with the potential to provide detailed maps of archaeological structures, showing up on the surface as a variety of so-called 'visibility marks': shadow marks revealing slight topographic variations, soil marks indicating varying chemical and physical properties, crop marks generated by variable growth of the vegetation, and frost or snow marks due to varying thermal properties.

The archaeological site of ancient Carnuntum is located in a landscape well suited for the utilisation of aerial photography: Roman remains are distributed over an area covering ten square kilometres, $80 \%$ of which are not built upon but are mainly used for agriculture. The soils are dominated by layers of gravel covered with loess. The climate is warm and dry with extended dry spells leading to the frequent development of highly visible crop marks related to buried archaeological structures, showing roads, trenches, houses, walls and pits. While the first aerial photographs date to the 1930s, most imagery was taken in the 1960s with the advent of systematic aerial archaeological prospection (Doneus and Neubauer 1997).

Several sets of vertical photographs of the area of Carnuntum taken in various years and at different seasons provide a very good overview of the archaeology of the entire area (Fig. 9.1). Through a collaboration with the Austrian Air Force based at Langenlebarn, vertical coverages have been collected and made available. The vertical photographs each overlap by circa $60 \%$ therefore allowing stereoscopic viewing and mapping. The photographs were exposed both on panchromatic and infrared false-colour film at scales ranging from 1:8000 to 1:15,000. Together with oblique aerial photographs (Fig. 9.2) taken from high-wing aeroplanes with smalland medium-format cameras using black-and-white as well as colour slide films and digital sensors, these images constitute an important data source. The advantage of the latter is the freedom of the experienced aerial archaeologist to choose the most suitable dates, times and position for the generation of high quality photographic documents, showing archaeological structures in the best detail. To date the archive of aerial photographs of the Institute for Prehistoric and Medieval Archaeology at Vienna University contains about 1500 vertical and oblique aerial photographs covering the area of Carnuntum.

Before a detailed interpretation of the archaeological features could take place, all of the relevant aerial photographs had to be georeferenced. First, the recent vertical coverages of the area were oriented using aerotriangulation and orthorectified by means of the Leica Photogrammetry Suite (LPS). In a second stage, the resulting orthophotographs provided ground control information for the georeferencing of further vertical and oblique aerial photographs (see also Doneus et al. 2001). 


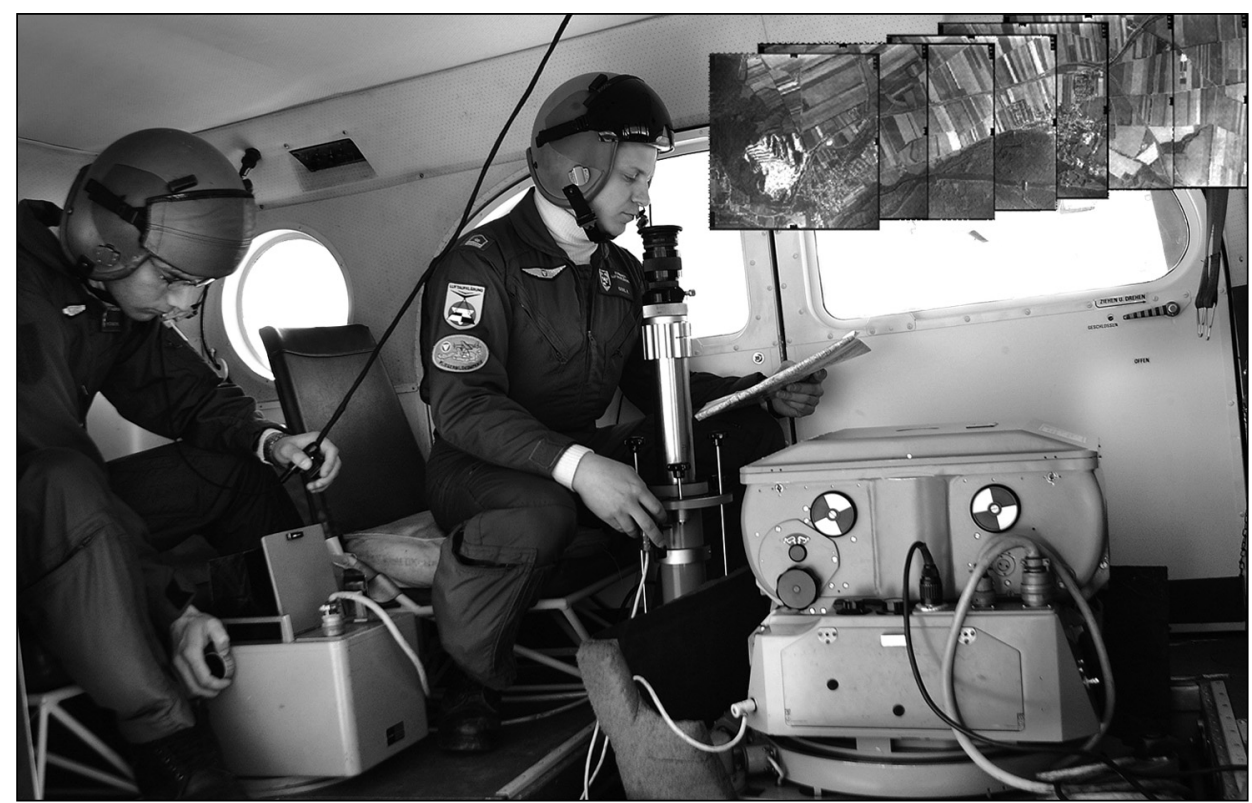

Figure 9.1: Series of panchromatic vertical aerial photographs taken by the Austrian Air Force with up to 60\% overlap between images permit three-dimensional viewing and stereoscopic mapping (LBI ArchPro and Austrian Air Force, Fliegerstaffel Langenlebarn).

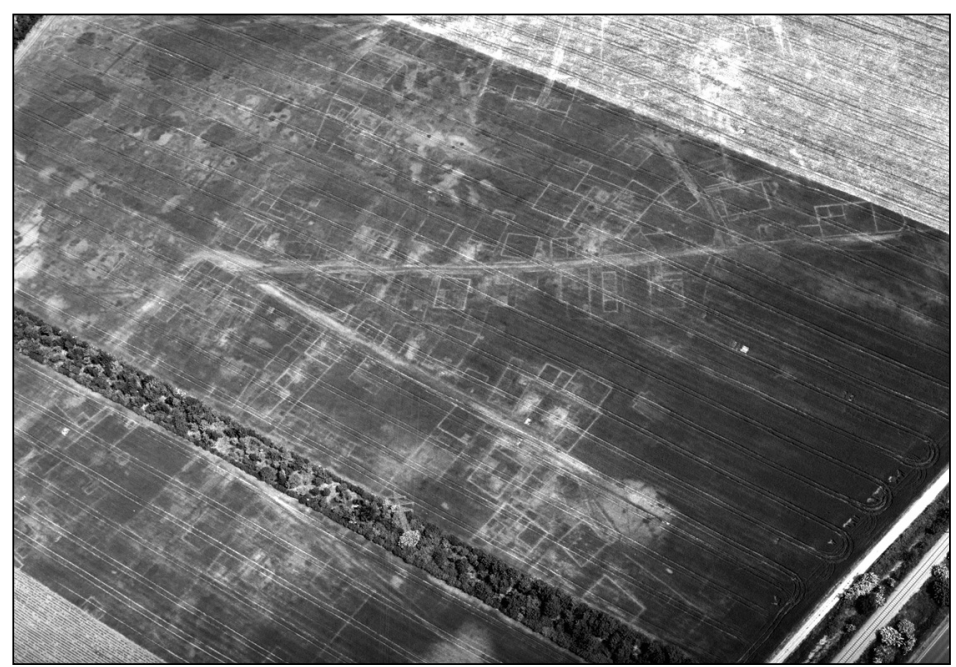

Figure 9.2: Oblique aerial colour photo showing crop marks caused by the remains of the Roman city. Foundations and walls of a large number of buildings and the paving of roads in the canabae legionis can be seen due to the reduction in soil humidity, causing growth changes of the vegetation above ground. Under suitable surface and soil conditions the method can be very effective for the detection and mapping of in particular Roman archaeological remains across large areas (Aerial Archive - University of Vienna). 
Altogether, more than 100 aerial photographs were rectified with accuracies better than $2 \mathrm{~m}$ (in most cases better than $1 \mathrm{~m}$ ). During the process of GIS-based interpretation, descriptive attribute values were added in the corresponding database. In the attached attribute table, each drawn feature has information about its description, function, and context, the number of the interpreted photograph, and the interpreter.

Up to the present, more than 7800 features have been mapped, covering an area of $11 \mathrm{~km}^{2}$ throughout Carnuntum and its surroundings (Fig. 9.3). In this way, we have demonstrated that aerial photography and the systematic analysis and interpretation of the images has great potential for the generation of large scale overviews and detailed survey of the archaeological structures hidden below the surface.

The latest addition to the aerial archaeological toolkit at Carnuntum is imaging spectroscopy. This technique, also called (hyper) spectral imaging, spectroscopic remote sensing, or imaging spectrometry, measures electromagnetic radiation in a multitude of spectral bands that are only a few nanometres wide. In other words: on each photosite of the imaging sensor, many bands of EM radiant energy are captured (typically, more than a hundred spectral bands; e.g. from $680 \mathrm{~nm}$ to $690 \mathrm{~nm}$, from $690 \mathrm{~m}$ to $700 \mathrm{~nm}$, etc.). The end product consists of spatially co-registered two-dimensional imagery in many spectrally contiguous bands, each image layer containing the reflectance values of a specific waveband. In this sense, imaging spectroscopy yields a three-dimensional data cube in which $\mathrm{X}$ and $\mathrm{Y}$ are the spatial dimensions, whereas the third axis $(\mathrm{Z})$ is a spectral dimension: holding the reflectance value of a particular waveband, sampled at that pixel location. Using the information of all acquired wavebands, a complete reflectance spectrum, the so-called spectral signature, for every individual pixel location can be derived.

When comparing these spectral signatures in the imagery with signatures yielded by ground-based spectrometer readings, it becomes possible to accurately distinguish the objects imaged. Moreover, very specific properties of these objects can also be exploited due to the small spectral ranges. By detecting subtle variations in the common spectral signatures, hyper-spectral data sets have the potential to reveal soil and crop marks more effectively, as it becomes possible to consider only those particular narrow spectral bands (or band combinations) in which the contrast is maximized between the undisturbed soil and plants, versus the soil and plants that are influenced by subsurface archaeological remains.

In the newly founded Ludwig Boltzmann Institute for Archaeological Prospection and Virtual Archaeology (LBI ArchPro), hyper-spectral aerial research is one of the main cornerstones. Besides the development of new techniques for the analysis and visualisation of these immense 3D data blocks, the LBI ArchPro also aims at determining those spectral regions that are most prone to archaeologically induced crop and soil discolorations. Therefore, repetitive spectral measurements are taken across archaeological areas and compared with zones believed to be undisturbed. Repeated measurements on a weekly timescale ensure that the entire cycle of crop growing and 


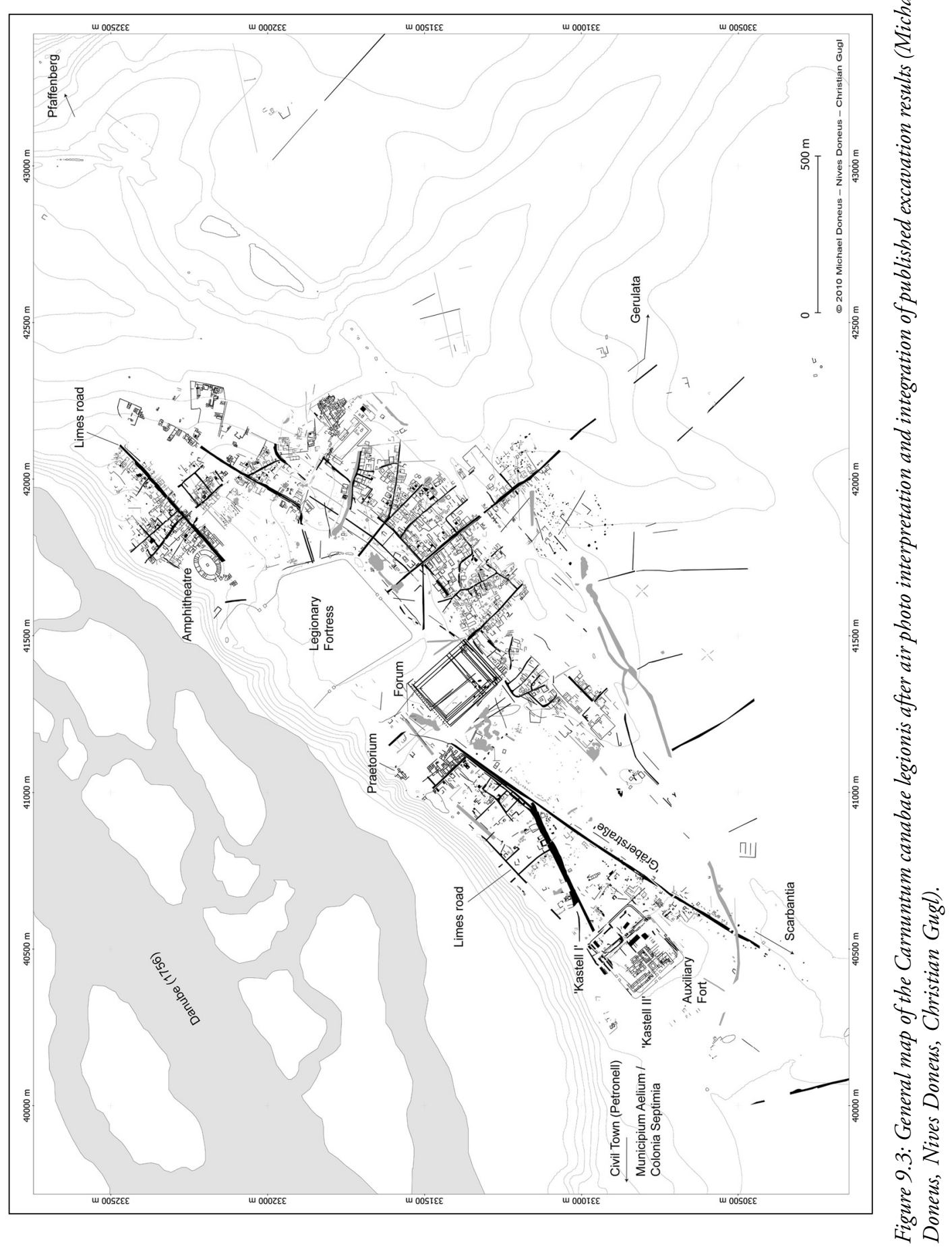


soil treatment is covered, which additionally should indicate the moments that are most favourable for the capture of airborne data.

\section{Geophysical archaeological prospection}

One of the basic problems of aerial archaeology is that the visibility of archaeological sites is dependent upon many factors. Most of these cannot be controlled and therefore, only a systematic reconnaissance programme lasting for many years will give a more or less complete overview of the archaeological subsurface.

Therefore, it is necessary to combine the aerial archaeological evidence with other prospection methods. At the University of Vienna, airborne remote sensing has been integrated with geophysical prospection research for more than 18 years. The archaeological park of Carnuntum has for many years functioned as a test site for the development of high-resolution near-surface geophysical archaeological prospection methods by the Vienna Institute for Archaeological Sciences (VIAS) and Archeo Prospections ${ }^{\oplus}$ of the Central Institute for Meteorology and Geodynamics (ZAMG). Large-scale magnetometry using arrays of very sensitive optically pumped Caesium magnetometers (Becker 1995; Neubauer 2001; Neubauer et al. 2001) in gradiometer configuration, earth-resistance measurements and ground-penetrating radar (GPR) surveys have been conducted at Carnuntum intermittently since 1990 . The geophysical prospection work was conducted in close correlation with the interpretation of the aerial archaeological evidence.

Within a 5 ha area where aerial archaeology had been unfruitful, an initial earth resistance survey was conducted, resulting in the discovery of a monumental building complex: enclosing an open square, this complex constitutes the long sought after forum of the civil town of Carnuntum (Kandler 1999). Additional magnetometer prospection of the entire neighbouring paddock (Fig. 9.4) as well as the survey of selected sub-areas with high-resolution GPR resulted in data of outstanding quality (Figs 9.5 and 9.6) and a wealth of new archaeological information.

The earth resistance measurements were conducted using two Geoscan RM15 meters and multiplexer MPX5 in twin-configuration in an initial survey interval of 0.5 $\times 0.5 \mathrm{~m}$ with two investigation depths (Clark 1990; Neubauer 2001, Neubauer et al. 2001). For the magnetometer prospection a Caesium gradiometer system with $0.1 \mathrm{nT}$ sensitivity was used with a $0.5 \times 0.25 \mathrm{~m}$ sample spacing (Neubauer et al. 1996). For the visualization of the geomagnetic data a data display range of $[-10+15] \mathrm{nT}$ was chosen and the earth-resistance values were plotted as 256 value greyscale image for the range $[80,180] \Omega \mathrm{m}$.

The results of the two geophysical methods display clear differences caused by the different physical contrasts involved. On the one hand, the earth-resistance measurements clearly show walls and pavements that are hardly or not at all visible in the magnetic prospection data, while on the other hand the magnetic prospection 


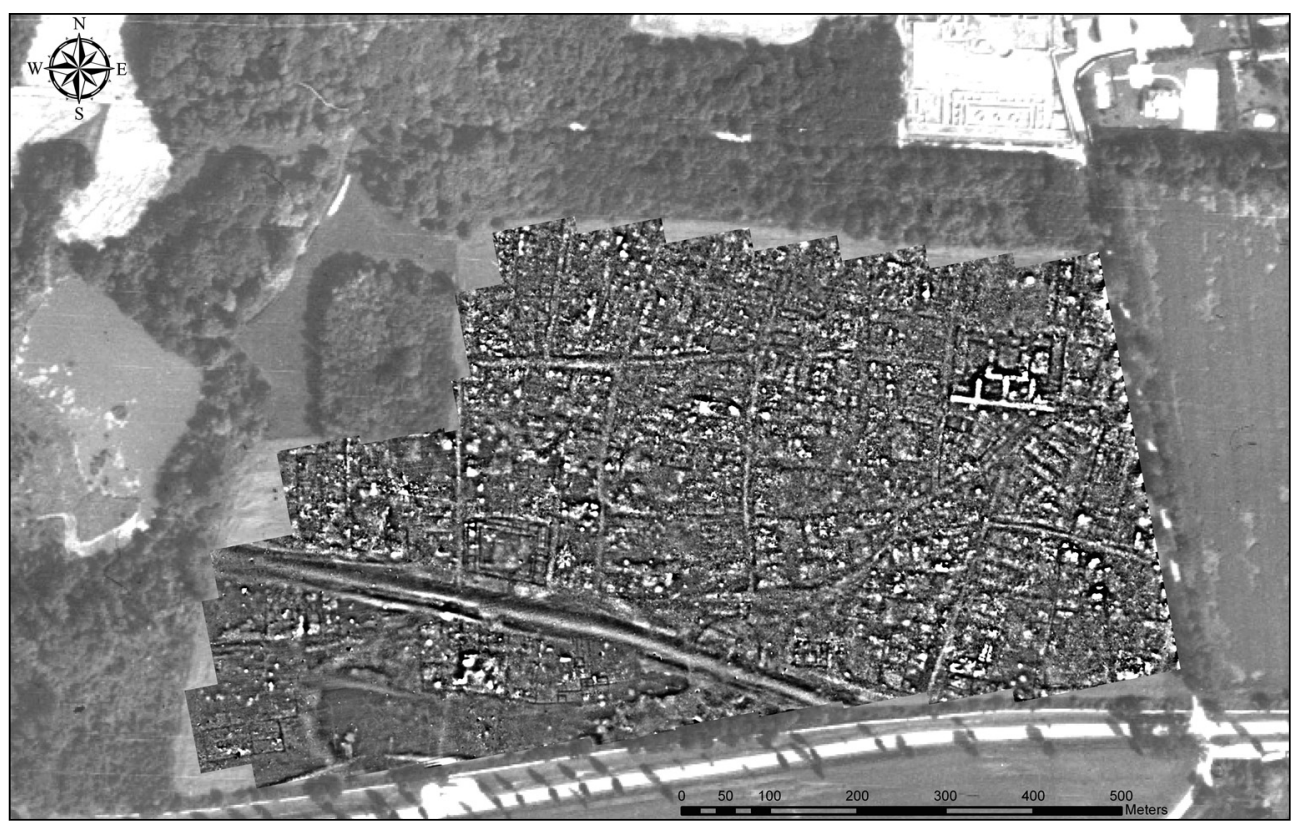

Figure 9.4: Results of large-scale high-resolution geomagnetic prospection conducted with a multi-sensor Caesium magnetometer superimposed within a GIS onto an aerial photograph. The dimension of the large field in the centre is $400 \mathrm{~m}(E-W) \times 200 \mathrm{~m}(N-S)$. In the northern part the excavated ruins of the public baths are visible. Numerous streets, lanes and buildings can be seen as linear magnetic anomalies crossing this part of the civil town of Carnuntum. The wide linear anomaly in the $S W$ is caused by the town fortification (rampart and trench); this structure and adjacent streets towards the $N$ are as well visible in the vertical aerial photograph. The strong magnetic anomaly in the NE part of the central survey area is caused by thermoremanent magnetised structures of the forum of Carnuntum, stretching towards the baths in the north (ZAMG Archeo Prospections ${ }^{\oplus}$ and VIAS-University of Vienna).

data show thermoremanent magnetised structures inside the buildings (Fig. 9.4). Thus, both data can contain different archaeologically relevant information about the investigated structure or building. Usually the individual data-sets would be interpreted separately and the independent interpretations subsequently merged in a synthesis. Here, the strategy involved the combination of both sets of measurements through digital image processing (Doneus and Neubauer 1998). The resulting new images - containing information from both sets of measurements - are then used in the following archaeological interpretation. Combining the images can be achieved in two different ways: on the one hand through arithmetic operations on the greyscale images (addition, difference, multiplication, division), and on the other hand through generation of colour images utilising the three RGB colour channels (Neubauer et al. 1999).

Using the mathematical addition of magnetic and resistance measurement values it is possible to bring out wall structures that are only weakly visible in the magnetic 


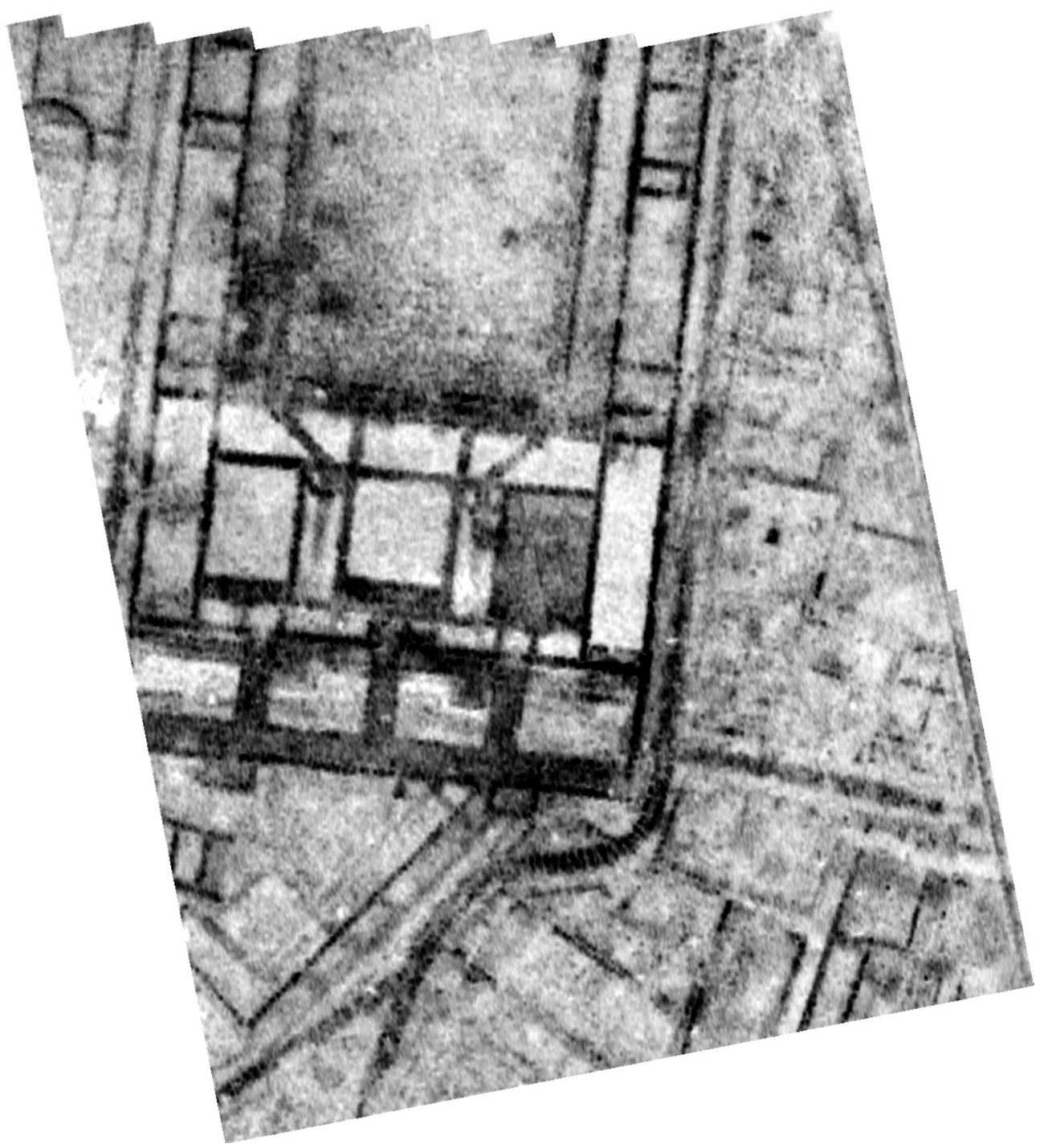

Figure 9.5: Close-up of a $0.15 \mathrm{~m}$ thick GPR depth-slice from approximately $1.5 \mathrm{~m}$ depth showing the southern part of the Roman forum in detail ( $0.05 \mathrm{~m}$ sample spacing in profile direction, 0.50 $m$ profile spacing) (ZAMG Archeo Prospections ${ }^{\circledR}$ and VIAS-University of Vienna).

images. At the same time strong anomalies caused by thermoremanent magnetisation are attenuated. The generation of difference images suppresses wall structures, and structures inside rooms become clearly visible, suggesting up to four different types of paving. Multiplication and addition, respectively division and subtraction lead to similar results (Neubauer and Eder Hinterleitner 1997). 


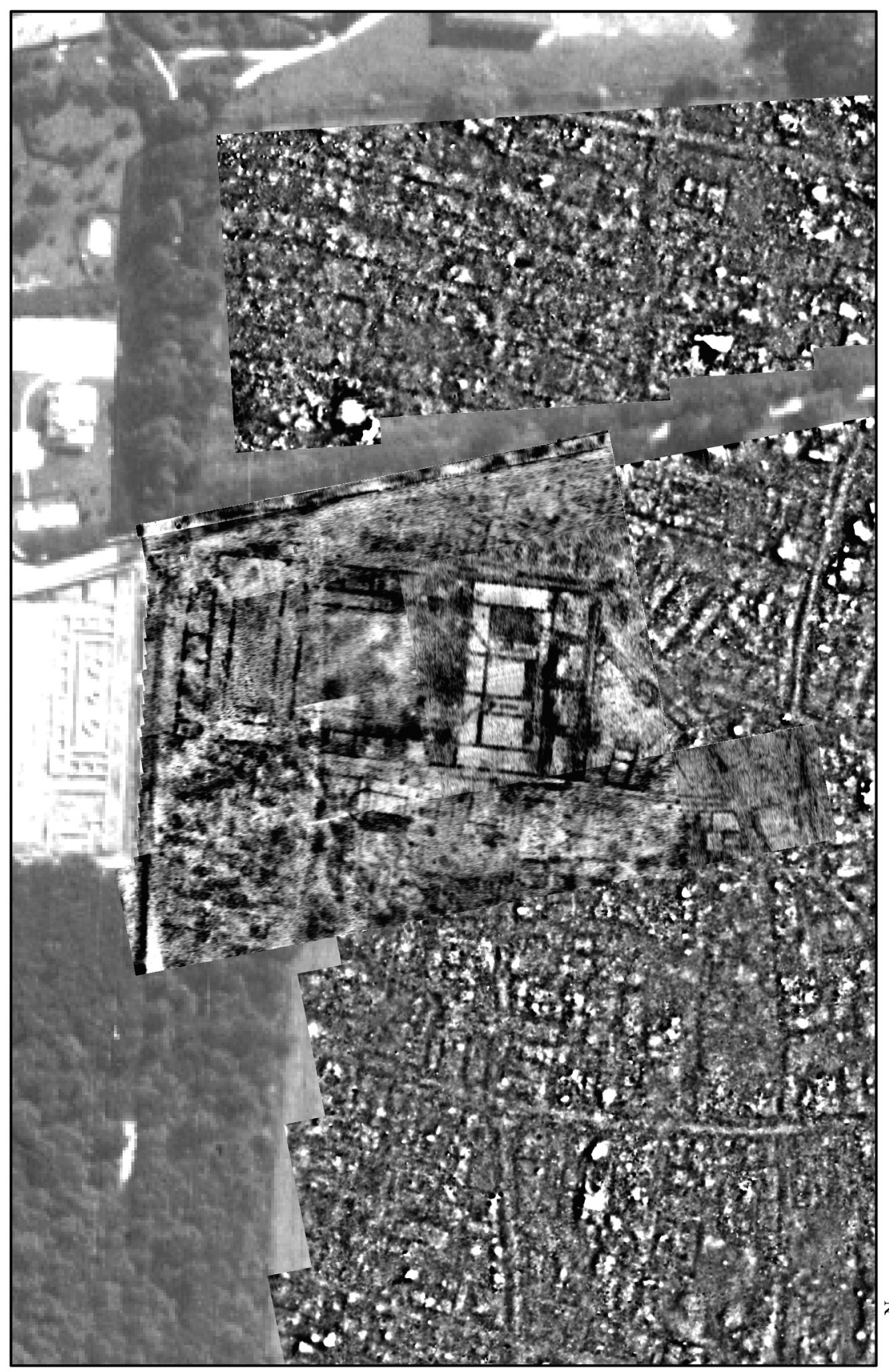

है

हैं

के

일

हुํํㄹำ

\&

8

$\approx$ के

\&

कै है

के०

인

논

\&

sos

:

है

은

논

के है ?

$\sqrt{1} \frac{8}{8}$

ठे है है

$\approx$

क

ค. है

खई कू

의 8

ค ริ รี

○)

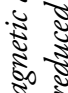

$\Xi$

कू

है

है।

(ี)

(1) है है

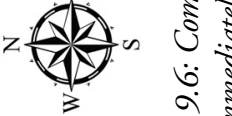

วิ.

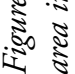


The earth resistance and magnetometer measurements result in two-dimensional data images. While magnetic prospection can be efficiently used for the fast mapping of large areas (several ha per day), GPR surveys permit the generation of detailed two- and three-dimensional images, containing detailed depth information (Fig. 9.6) about the buried archaeological structures (Goodman 1994; Conyers and Goodman 1997; Neubauer 2001; Leckebusch 2003). In contrast to the first two methods, which have been in standard use in archaeological prospection for years, the integration of the GPR method required the determination of suitable measurement configurations and corresponding parameters, as well as the development of appropriate processing routines for the integration of the GPR data into the GIS-based interpretation process. For this purpose extensive test measurements were conducted at Carnuntum and dedicated applicable software and visualisation techniques were developed starting in 1998. Similar to the earlier applied earth-resistance method, the GPR measurements proved to be well suited for the detection of wall structures at Carnuntum. In particular the electric properties of the soil affect the GPR signal during its passage through the subsurface. The magnetic prospection resulted in relevant extra information on magnetised structures, such as hypocausts, pits, hearths, ovens and brick structures. In case of Roman remains and city sites the combination of GPR and magnetic prospection is of particular importance (Figs 9.4, 9.6, 9.7). While GPR surveys are based on similar soil properties as earth-resistance measurements, they have considerable advantages over the latter:

- the information obtained is three-dimensional and of considerably greater spatial resolution;

- the GPR survey speed is considerably faster;

- in urban environments GPR surveys are even possible on sealed surfaces.

Since GPR measurements are also much less affected by external disturbances than magnetometer measurements, it is possible to use the GPR method at many sites that are unsuitable for magnetic surveys. The fundamental basics of the GPR method in archaeology have been described in detail by Conyers and Goodman (1997) and Leckebusch (2003).

For archaeological applications, GPR systems with antennae operating with mean frequencies of $200 \mathrm{MHz}$ to $1000 \mathrm{MHz}$ are most commonly used. Measurements are conducted continuously with sample spacings of $0.02-0.05 \mathrm{~m}$ along the line of measurement and $0.25-0.50 \mathrm{~m}$ between parallel survey lines (also called profile spacing).

At Carnuntum, the first GPR tests in 1998 were conducted with $225 \mathrm{MHz}$ and 450 $\mathrm{MHz}$ GPR antennae. For the initial survey the $450 \mathrm{MHz}$ antenna was used with 0.05 $\mathrm{m}$ sample spacing and $0.50 \mathrm{~m}$ profile spacing. Several measurements in perpendicular survey direction $(\mathrm{x} / \mathrm{y})$ were conducted covering the same, $80 \times 80 \mathrm{~m}$ large site. These pilot studies showed the effect of survey orientation and sample density on the resulting data images (Neubauer et al. 1999). 
The processing of the three-dimensional data volume constructed from the individual GPR sections is fully automated using the specially in-house developed software APRadar and can be conducted within minutes while still in the field. By applying standard filter settings, geo-referenced amplitude-slice images (Goodman et al. 1995) for use in GIS can be immediately generated for complex survey areas of any shape.

Further image processing and advanced visualisation is possible through the use of commercial 3D visualisation software such as AVS, supporting the presentation and interpretation of the data. The generation of animation sequences scrolling quickly through a stack of depth-slices or displaying amplitude variations are very useful tools for the analysis and understanding of the data. The final data interpretation is undertaken within the framework of a GIS, such as ArcGIS, in which integrative archaeological interpretations are generated based on all available georeferenced data (Fig. 9.7).

In case of the monumental building complex of the forum of Carnuntum it has been possible to extract detailed depth-dependent information by moving through the threedimensional data volumes from top to bottom, and to map the remains of individual

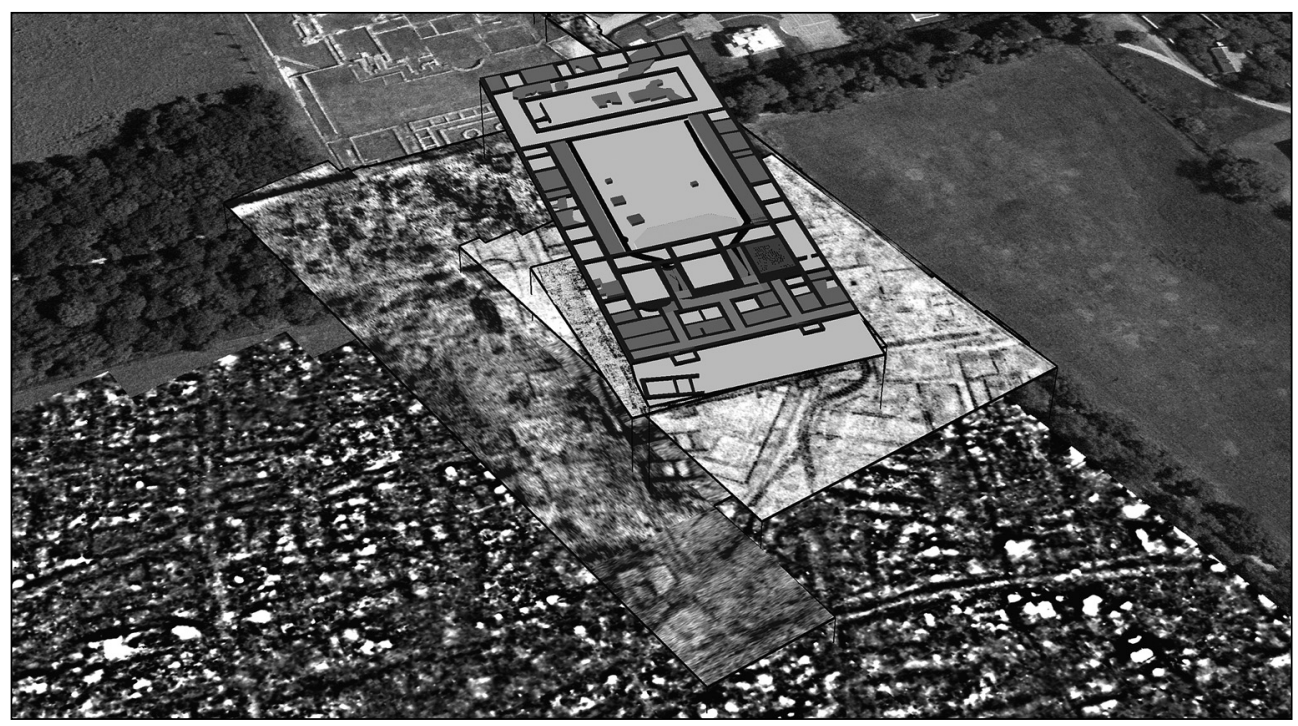

Figure 9.7: Perspective view of the archaeological interpretation of the forum of Carnuntum (top), based on the integrated analysis of the aerial (bottom layer), magnetic (layer 1), earth resistance (layer 2) and GPR data (layers 3 and 4). The rectangular building complex covers an area of circa $3000 \mathrm{~m}^{2}$. The width of the complex is $66 \mathrm{~m}$ and the length $140 \mathrm{~m}$. The open space in the centre has a width of $36 \mathrm{~m}$. The southern front is separated into three larger halls. The easternmost hall shows signs for the existence of a compact stone floor or paving, and the magnetic data indicates the presence of a hypocaust heating system. Channels seem to go out from the western and eastern hall, crossing the adjacent northern rooms diagonally and running northward under the central courtyard. Several flights of stairs that clearly can be identified in the GPR data are marked in the interpretation (ZAMG Archeo Prospections and VIAS-University of Vienna). 
constructions such as walls, drains, pavements, corridors, foundations, column bases and other internal details over an area covering 5 ha. This even permitted the identification of staircases and hypocaust systems within the main building.

Since the first combined prospection attempts, a considerable number of further areas have been investigated in detail at Carnuntum using the tested archaeologicalgeophysical survey strategy, resulting in valuable information about the location of buildings, depth of foundations, filling materials, floors and pavements, the height of preservation of individual structures and the depth of destruction caused by ploughing. The results generated through such prospection are outstanding and revealed some spectacular finds as the recently detected and virtually reconstructed school of gladiators (http://7reasons.at/Carnuntum).

\section{Archaeological interpretation in GIS and virtual archaeology}

Archaeological interpretation is done using GIS. To be able to overlay orthophotos, geophysical images and vector shapes, these have to be set up in a uniform coordinate system, a prerequisite that is already fulfilled by the data described here. The interpretation drawings derived from GPR-data were combined with the available earth-resistance and magnetic data as well as information gained from aerial photography to provide a detailed archaeological interpretative model. Both two-dimensional interpretation maps and three-dimensional interpretation models can be derived from this basis.

The orthophotographs from aerial archaeology are enhanced using digital image processing techniques such as contrast enhancement, Wallis-filter and crispening to make the archaeological features better visible. All of the georeferenced orthophotographs and their filtered versions are then compiled in the GIS viewer.

The on-screen interpretation is done image by image in separate layers using different colours and attributes for different features. Since every image shows the area in different conditions and in different detail, the composite interpretation drawing is summarising the information visible on all available photographs.

As already noted, most archaeological structures appearing in aerial photographs could be mapped during the last few years. Consequently, it is possible to present an overview of the settlement layout of the military town. In the canabae around the military camp the entire road network - partly with side drains - could be reconstructed. Between the roads, more than a hundred buildings have been identified. West of the camp parts of the forum are visible. The main road leading to the west is accompanied by several graves and tombs. Further west the ditches of the auxiliary camp, in which cavalry were based, were mapped. The camp has already been partly destroyed by the expansion of the village of Petronell. The second area, west of this village, shows a complex of buildings belonging to the civil amphitheatre II and a large graveyard, which is partly intersecting and therefore not contemporary. The civil town of Carnuntum 
was protected by a town wall and two parallel ditches. Since the area of the civil town is under grassland, archaeological features can only be seen in very dry summers; in most of the photographs only the road network is visible.

Even more detail can be seen in the results of the geophysical prospection (Neubauer et al. 2002). A large building complex with symmetrical layout covering an area of over $3000 \mathrm{~m}^{2}$ and a wall thickness of up to $1.5 \mathrm{~m}$ - forming the southern end of the forum of Carnuntum - was explored in this case study (Fig. 9.8). The northern part of this building complex could be reached from the lower open square of the forum via a monumental stairway and contained three large halls of $150 \mathrm{~m}^{2}$. The western of these halls had an apse, while the corresponding hall to the east is equipped with hypocausts and thus could be heated, probably being the curia. The central hall shows a pedestal or platform in front of the back wall. In the southern part small rooms partly constructed with cellars are flanked by corridors. These were reached by two stairways and a porticus from another triangular space to the south. The rooms lining the forum with a porticus presumably housed shops with cellars. Below the floor level of the building two channels/drains leading to the river Danube were traced. Besides these important features additional information about depth of foundations, filling layers and plastering as well as the height of the remaining walls and the position

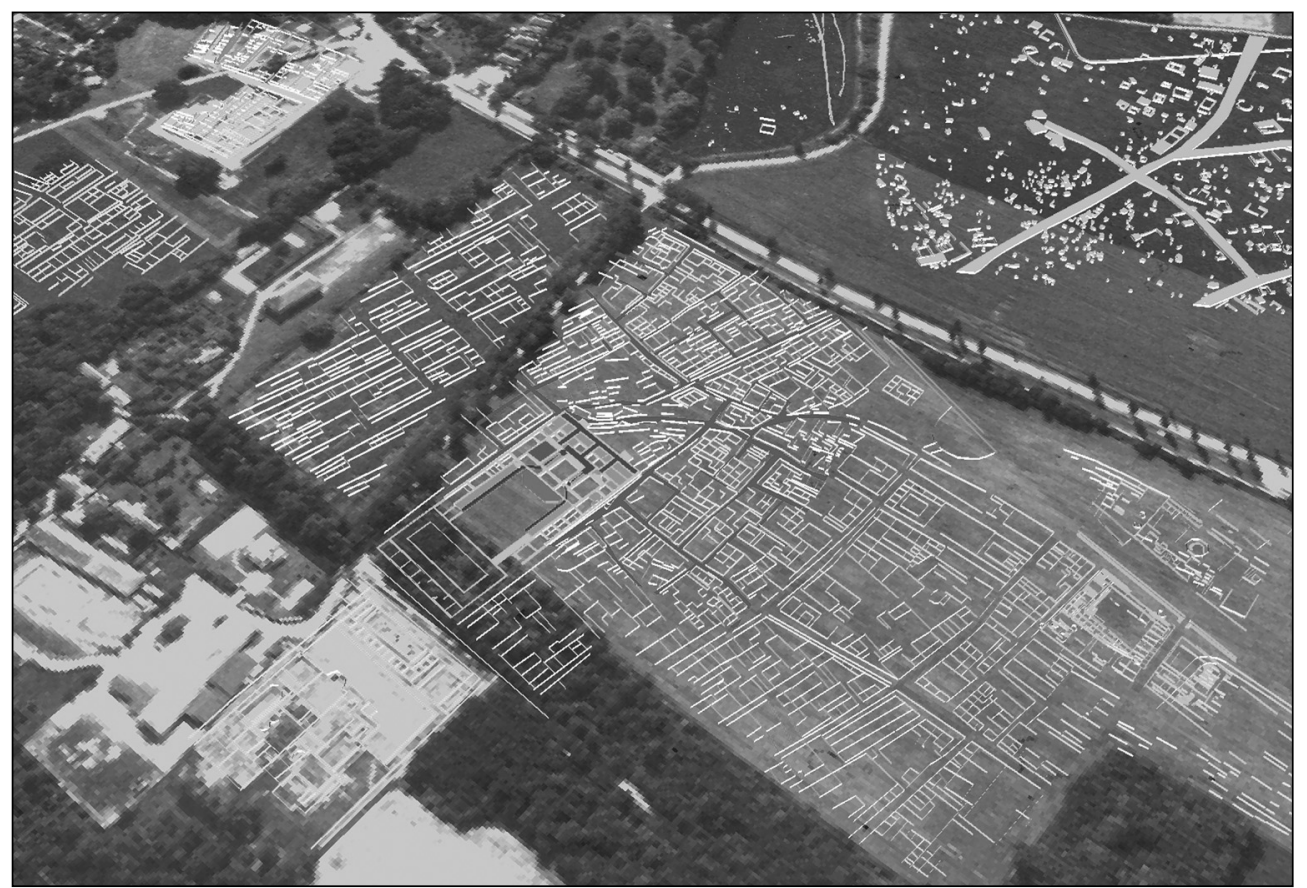

Figure 9.8: The archaeological interpretation of the survey data presented in a three-dimensional visualisation (VIAS-University of Vienna). 
of wall debris and the penetration depth of modern ploughs could be documented (Neubauer et al. 2005).

It is not our intention to give a full description of the mapped features which would be beyond the scope of this article. However, this very crude description provides already an impression of the great variety of structures and the high degree of detail possible (see also Neubauer and Hinterleitner 1997; Neubauer et al. 1999).

The archaeological approach of the proposed strategy is essentially technological, multidisciplinary and virtual (in the scientific sense of the word), as it is linked to computerised data capturing, processing, simulation and VR visualisation (HirscheggerRamser et al. 1999; Ferschin et al. 2001) and reconstruction of the non-material aspects of archaeology, e.g. the re-creation of surfaces and volumes.

\section{Conclusions and the road ahead}

The combination of advanced methods of airborne remote sensing, geophysical prospection and geomatics permits the efficient and highly accurate detection, investigation and documentation of archaeological sites above and below the ground. Until recently archaeology used the great potential offered by these modern prospection techniques only to a limited extent. Large-scale prospection methods and their integrated interpretation, as outlined in this paper, provide a wide range of spatial data.

Aerial archaeological imagery provides an important foundation for any kind of spatial archaeology (settlement-, environmental- or landscape archaeology) by offering possibilities for efficient archaeological site detection and identification. Georeferenced rectified vertical and oblique aerial photos from reconnaissance flights are used to derive the archaeological interpretation of detected structures or features. In that way, repetitive observations can be combined into an extensive overall view of an archaeological region, which can be used as basic information for further prospecting, excavations, protection measures, and spatial archaeology.

Additionally, modern archaeological remote sensing techniques, such as airborne hyper-spectral scanning (AHS) and airborne laser scanning (ALS), open promising new perspectives for the extraction of information on buried archaeological remains and the generation of highly detailed digital terrain models.

Regarding geophysical archaeological prospection, an increase in measurement efficiency of geophysical prospection methods is needed in order to render their archaeological application more economical and therefore attractive for largescale prospection. New technologies concerning the development of multichannel instruments (Leckebusch 2005) and advanced positioning and navigation systems offer novel possibilities for large-scale archaeological geophysical prospection. Motorised measurement devices for rapid, high-resolution magnetometer and GPR prospection are now being designed and built (Fig. 9.9). Together with the development and 


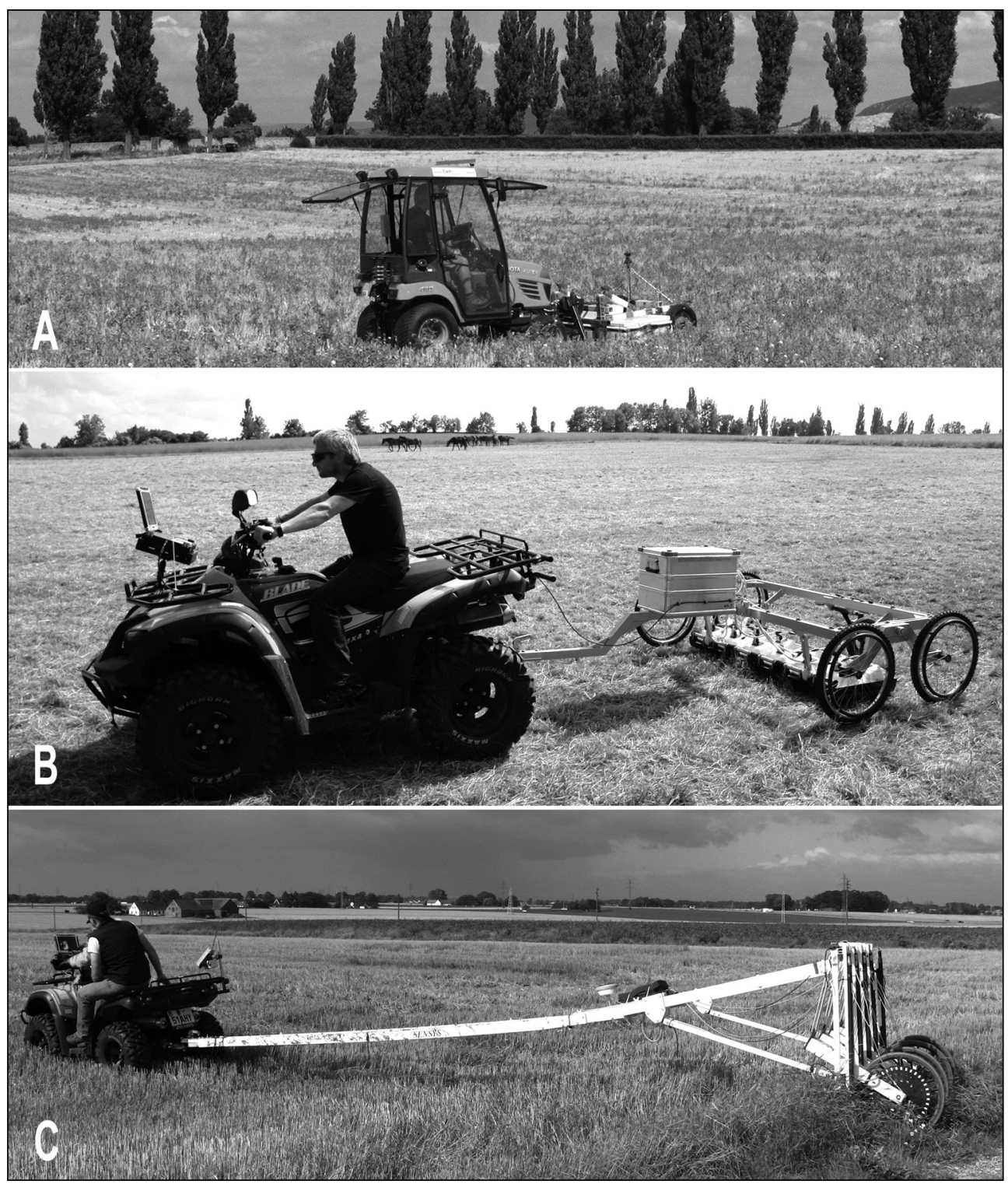

Figure 9.9: Novel motorised survey systems. A) The MALA Imaging Radar Array consisting of 16 GPR antennae ( $400 \mathrm{MHz}$ ) mounted in front of a gardening tractor with $0.08 \mathrm{~m}$ channel spacing and a robotic total-station for positioning. B) The six channel SPIDAR GPR system consisting of six $500 \mathrm{MHz}$ PulseEkko Pro antennas (Sensors \& Software) towed with $0.25 \mathrm{~m}$ channel spacing behind an ATV Quad bike. C) A motorized multi-sensor fluxgate magnetometer system, consisting of five Foerster gradiometer probes mounted with $0.50 \mathrm{~m}$ channel spacing behind an ATV. Positioning is implemented using a differential RTK GPS (Ludwig Boltzmann Institute for Archaeological Prospection and Virtual Archaeology). 
implementation of automated positioning systems as well as adequate data processing and visualisation techniques, new and highly efficient archaeological survey and prospection systems will become available. The motorised survey of the forum of Carnuntum in December 2009 using a 16-channel MALÅ Imaging Radar Array with only $0.08 \mathrm{~m}$ measurement spacing in the direction of the GPR profiles and $0.08 \mathrm{~m}$ profile spacing for the first time imaged the hypocaust pillars in the eastern room of the monumental southern forum building (Fig. 9.10). It goes without saying that the fascinating resolving power and efficiency of the new technology will in the near future permit many more groundbreaking discoveries when applied on Roman city sites. However, the integrated archaeological interpretation strategy here presented had already suggested the presence of remains of a hypocaust system in this specific room in 2001 (Neubauer et al. 2002).

The resulting complex three-dimensional datasets of archaeological sites and their surrounding landscapes demand better integrated archaeological interpretation and the development of novel concepts of dynamic analysis, including temporal relations and

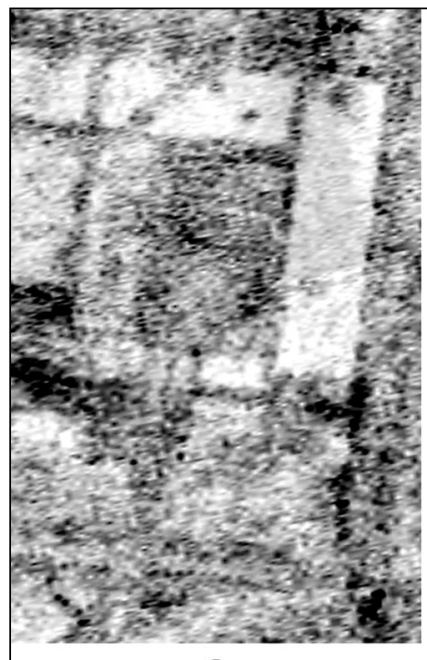

a

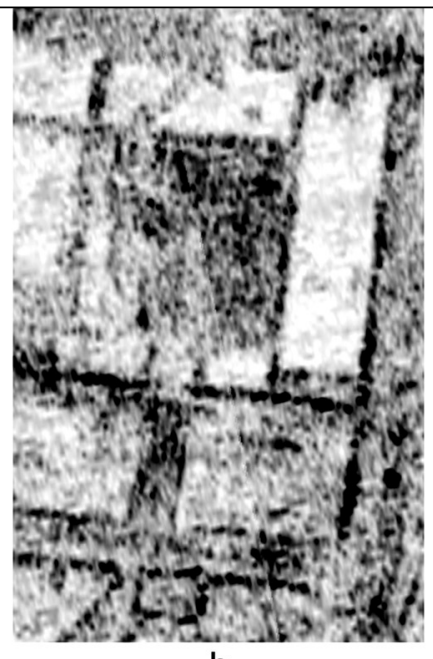

b

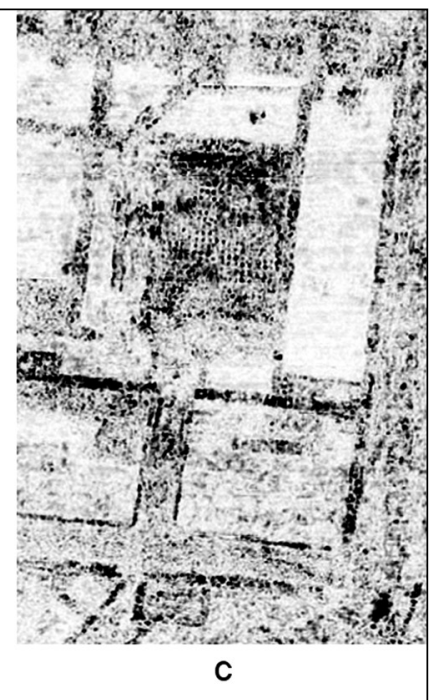

C

Figure 9.10: Advances in GPR prospection between 1998 and 2009 due to new instrumentation, higher spatial resolution and advanced data processing. Time-slices at $1.5 \mathrm{~m}$ depth of an area covering $35 \times 54 \mathrm{~m}$ over the eastern hall interpreted as the curia at the Roman forum of Carnuntum. a) GPR result 1998, Sensors and Software PulseEKKO 1000 system with $450 \mathrm{MHz}$ antennae, spatial resolution: $0.50 \times 0.20 \mathrm{~m}$; b) GPR result 2005, Sensors and Software Noggin Plus system with 250 MHz antennae, spatial resolution: $0.50 \times 0.05 \mathrm{~m} ; \mathrm{c}$ ) GPR result 2009, MALA Imaging Radar Array system with $400 \mathrm{MHz}$ antennae, spatial resolution: $0.08 \times 0.08 \mathrm{~m}$. In image $c$ the individual, in regular intervals arranged brick pillars of the hypocaust system are for the first time clearly visible due to the high spatial resolution. The presence of this hypocaust system had already been predicted in 2001 by the integrative archaeological interpretation of the magnetic and earth resistance data (Ludwig Boltzmann Institute for Archaeological Prospection and Virtual Archaeology). 
attributes. Therefore a major challenge remains the transformation of the acquired and processed complex physical data into interpretative archaeological information that is accurate, readable and ready for other archaeologists to use, enabling them to derive and integrate spatial and temporal information in order to gain information of the fourth dimension: time. Specific GIS-tools will need to be derived from the prospection experts' interpretation process and downgraded to an integrated, easy-to-use multi-purpose toolbox for the archaeologist. In the end, this should provide a common graphical interface for the communication between the prospection experts and the archaeologists experienced in specific spatial or temporal aspects of the site and landscape under research. The archaeological data interpretation toolbox will have to be extended to include easyto-use tools for dynamic visualisation and integrated archaeological interpretation, data archiving, information retrieval and long-term maintenance.

Large-scale, high-resolution state-of-the-art magnetometry and GPR surveys - as essentially developed and applied by the new Ludwig Boltzmann Institute for Archaeological Prospection and Virtual Archaeology and its partner organisations - will become the most important and widely used tools in future large-scale archaeological geophysical prospection, and are ideally suited for the survey of Roman city sites.

Both nationally and internationally the case study Carnuntum is exemplary for an integrative use of state-of-the-art archaeological prospection methods. Existing and specifically recorded aerial photographs permit an overview across the entire archaeological city site. Area-wide, non-destructive geophysical prospection using magnetic, earth resistance and GPR methods and their resulting digital images complete and expand the information contained in the aerial photographs with great detail. Moreover, digital image processing can even enhance existing data, allowing the fast and cost efficient generation of detailed maps of buried archaeological monuments. These documents are of fundamental importance for cultural heritage management and planning control, and serve as cost effective scientific documentation of buried archaeology for the research community.

\section{Bibliography}

Becker, H. 1995. From Nanotesla to Picotesla a new window for magnetic prospecting in archaeology. Archaeological Prospection 2. 217-228.

Clark, A. 1990. Seeing Beneath the Soil. London: Batsford.

Conyers, L. B. and Goodman, D. 1997. Ground Penetrating Radar. An introduction for archaeologists. Walnut Creek: Altamira Press.

Council Of Europe, 1992. European Convention on the Protection of the Archaeological Heritage (Revised). Convention européenne pour la protection du patrimoine archéologique (révisée). Valetta, 16.I.1992.

Doneus, M. and Neubauer, W. 1997. Archäologische Prospektion in Österreich. Archäologie Österreichs 8. 19-33. 
Doneus, M. and Neubauer, W. 1998. 2D Combination of Prospection Data. Archaeological Prospection 5. 29-56.

Doneus, M., Doneus, N. And Neubauer, W. 2002. Integrated archaeological interpretation of combined prospection data, Zwingendorf (Austria) - a case study. In Bewley, R.H. and Raczkowski, W. (eds) Aerial Archaeology. 149-165. Amsterdam: IOS Press.

Doneus, M. and Neubauer, W. 2005. Multiple survey techniques at Roman Carnuntum. Integrated prospection of the largest archaeological landscape in Austria. In Musson, C., Palmer, R. and Campana, S. 2005. In volo nel passato. Aerofotografia e cartografia archaeologica. Biblioteca del dipartimento di archaeologia e storia delle arti - sezione archaeologica, Università di Siena. 272-279. Firenze: All'Insegna del Giglio.

Doneus M., Eder-hinterleitner, A. and Neubauer, W. 2001. Roman Carnuntum - prospecting the largest archaeological landscape in Austria. In Doneus, M., Eder-Hinterleitner, A. and Neubauer, W. (eds) Archaeological Prospection, 4th int. Conference. 47-59. Vienna: Austrian Academy of Sciences.

Eder-hinterleitner, A., Melichar, P., Neubauer, W., Doneus, M. and Seren, S. 2003. The city map of ancient Carnuntum - combining archaeological prospection, photogrammetry and GIS. Archaeologia Polona 41. 156-157.

English Heritage 2008. Geophysical Survey in Archaeological Field Evaluation. Research and Professional Services Guideline No. 1 (revised versions). English Heritage Ancient Monuments Laboratory. http://www.english-heritage.org.uk/upload/ pdf/GeophysicsGuidelines.pdf

Ferschin, P., Hecher, P., Kandler, M. and Neubauer, W. 2001. Virtual reality reconstruction of the Roman town Carnuntum (Austria). In Doneus, M., Eder-Hinterleitner, A. and Neubauer, W. (eds) Archaeological Prospection, 4th int. conference Vienna. 102. Vienna: Austrian Academy of Sciences.

Gaffney, C. F. and Gater, J. 2003. Revealing the Buried Past: geophysics for archaeologists. Stroud: Tempus.

Goodman, D. 1994. Ground penetrating radar simulation in engineering and archaeology. Geophysics 59(2). 224-232.

Goodman, D., Nishimura, Y. and Rogers, J. D. 1995. GPR Time slices in archaeological prospection. Archaeological Prospection 2. 85-89.

Hirschegger-ramser, P., Ferschin, P., Kandler, M. and Neubauer, W. 1999. Computer aided virtual reality reconstruction based on prospection data. An example from the Roman town Carnuntum/Austria. In Faßbinder J. and Irlinger W. (eds) Arbeitshefte des Bayerischen Landesamtes für Denkmalpflege, Band 108. 41-42.

Joвst, W. 1983. Provinzhauptstadt Carnuntum. Österreichs größte archäologische Landschaft. Himberg: Wiener Verlag.

KAndler, M. 1994. Carnuntum - Auxiliarkastell und Vicus. Jahreshefte des Österreichischen Archäologischen Institutes Band 64, Beiblatt. 46-50.

Kandler, M. 1997. Carnuntum. In Friesinger, H. and Krinzinger, F. (eds) Der römische Limes in Österreich. Führer zu den archäologischen Denkmälern. 258-272. Wien: Verlag Österreichische Akademie.

Kandler, M. 1998. 100 Jahre Österreichisches Archäologisches Institut, 1898-1998. Forschungen in Carnuntum. Begleitband zur Bilddokumentation. Wien: Österreichisches Archäologisches Institut.

Kandler, M. 1999. Das Forum der Colonia Carnuntum. Erste Ergebnisse von geophysikalischen Bodenprospektionen im Tiergarten des Schlosses Petronell. Sonderschriften des Österreichischen Archäologischen Institutes 32. 359-368.

Kandler, M., Neubauer, W. and Doneus, M. 2001a. The eastern front of the auxiliary camp at Carnuntum (Austria). In Doneus, M., Eder-Hinterleitner, A. and Neubauer, W. (eds) Archaeological Prospection, 4th int. Conference. 128-129. Vienna: Austrian Academy of Sciences.

Kandler, M., Neubauer, W., Eder-hinterleitner, A. and Melichar, P. 2001b. The Gräberstrasse of Carnuntum (Austria). In Doneus et al., 2001. Archaeological Prospection, 4th Int. Conference. 124-128. Vienna: Austrian Academy of Sciences. 
Leckebusch, J. 2003. Ground-penetrating Radar: A Modern Three-dimensional Prospection Method. Archaeological Prospection, 10, 213-240.

Leckebusch, J. 2005. Use of antenna arrays for GPR surveying in archaeology. Near Surface Geophysics 3. 107-111.

Lorra, S. 1996. Geophysikalische Prospektion und Modellierung archäologischer Fundplätze in SchleswigHolstein. Universitätsforschungen zur prähistorischen Archäologie Bd. 36. Bonn: Rudolf Habelt.

Neubauer, W. 1990. Geophysikalische Prospektion in der Archäologie. Mitteilungen der Anthropologischen Gesellschaft in Wien 120. 1-60.

Neubauer, W., Eder-hinterleitner, A. and Melichar, P. 1996. Collection, visualization and simulation of magnetic prospection data. In Kamermans, H. and Fennema, K. (eds) Computer Applications and Quantitative Methods in Archaeology CAA95 Vol. 1. Analecta Praehistorica Leidensia 28. 121-129.

Neubauer, W. and Eder-hinterleitner, A. 1997. Resistivity and magnetics of the Roman town Carnuntum/Austria: an example of combined interpretation of prospection data. Archaeological Prospection 4. 179-189.

Neubauer, W., Eder-hinterleitner, A., Seren, S., Doneus, M. and Melichar, P. 1999. Kombination archäologisch-geophysikalischer Prospektionsmethoden am Beispiel der römischen Zivilstadt Carnuntum. Archaeologia Austriaca 82/83. 1-26.

Neubauer, W. 2001. Magnetische Prospektion in der Archäologie. Mitteilungen der Prähistorischen Kommission 44. Wien: Verlag der Österreichischen Akademie der Wissenschaften.

Neubauer, W., Eder-hinterleitner, A., Melichar, P. and Steiner, R. 2001. Improvements in high resolution archaeological magnetometry. Prospezioni Archeologiche 11. 113-134.

Neubauer, W., Eder-hinterleitner, A., Seren, S. and Melichar, P. 2002. Georadar in the Roman civil town Carnuntum/Austria: an approach on archaeological interpretation of GPR data. Archaeological Prospection 9. 135-156.

Neubauer, W. 2004. GIS in archaeology - the interface between prospection and excavation. Archaeological Prospection 11. 159-166.

Neubauer, W., Eder-hinterleitner A. And Seren, S. 2005. Large Scale GPR Surveys of Roman Buildings. In Kars, H. and Burke, E. (eds) Proceedings of the 33rd international Symposium on Archeometry. Geoarchaeological and Bioarchaeological Studies 3. 23-30. Amsterdam: Vrie Universitie.

Scollar, I., Tabbagh, A., Hesse, A. and Herzog, I. 1990. Archaeological Prospecting and Remote Sensing. Cambridge: Cambridge University Press.

Vorbeck, E. and Beckel, L. 1973: Carnuntum - Rom an der Donau. Salzburg: Otto Müller Verlag. 